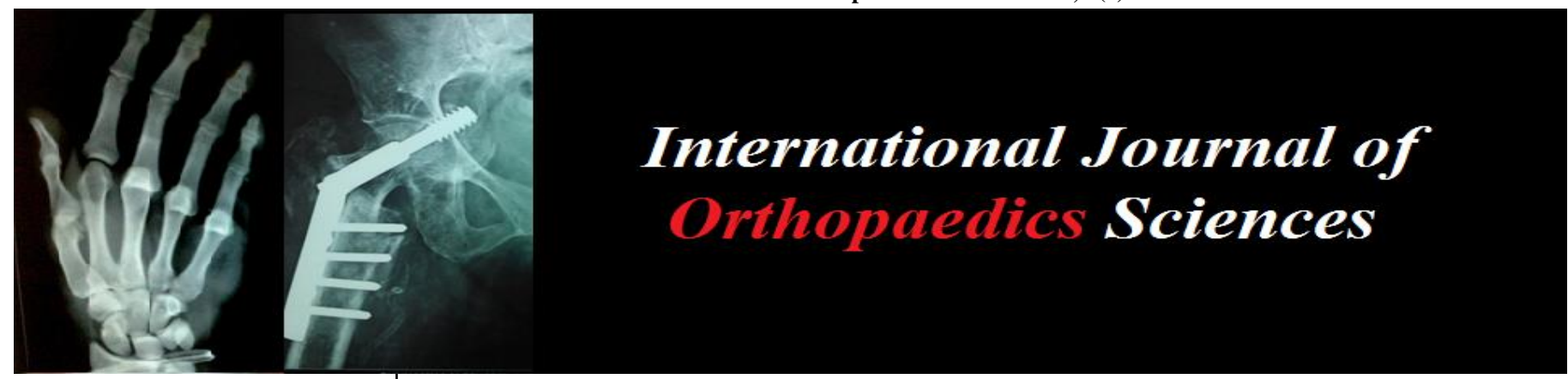

E-ISSN: 2395-1958

P-ISSN: 2706-6630

IJOS 2020; 6(4): 97-99

(C) $2020 \mathrm{IJOS}$

www.orthopaper.com

Received: 17-08-2020

Accepted: 21-09-2020

Dr. Nikhil Challawar

Assistant Professor, Department

of Orthopedics, Dr.

Vasantraopawar Medical College

Hospital and Research Center.

Nashik, Maharashtra, India

Dr. Vishwesh D Chudasama

Resident at Department of

Orthopedics, Dr.

Vasantraopawar Medical College

Hospital and Research Center.

Nashik, Maharashtra, India

Dr. Shubham S Zade

Resident at Department of

Orthopedics, Dr.

Vasantraopawar Medical College

Hospital and Research Center,

Nashik, Maharashtra, India

\section{Sprengel deformity: Reproducibility of Woodward's procedure in terms of cosmesis and range of motion}

\author{
Dr. Nikhil Challawar, Dr. Vishwesh D Chudasama and Dr. Shubham S \\ Zade
}

DOI: https://doi.org/10.22271/ortho.2020.v6.i4b.2326

Abstract

Purpose: Our study aims to report the functional and cosmetic results of the patients with Sprengel's shoulder who were operated using the Woodward procedure.

Materials and methods: Five children were operated at mean age of 6.2 years and the children were reviewed at an average follow up of 24 months. Cosmesis was assessed using Cavendish score preoperative and post- operatively. Functional outcome was assessed by measuring shoulder range of abduction clinically using goniometer.

Results: The mean pre-operative Cavendish score was 2.6 which reduced to 1.2 at final review. The range of shoulder abduction on the involved side increase from 102.2 degrees to 135 degrees at follow up, thus showing an improvement of 32.8 degrees.

Conclusion: The Woodward's procedure is a reliable procedure for correcting Sprengel's deformity and to achieve good cosmesis and functional outcome.

Keywords: Scapula, Sprengel deformity, Woodward procedure

\section{Introduction}

Sprengel deformity also known as congenital elevation of scapula though not first reported by Otta Gerhard Karl Sprengel but in 1891 drew attention to this deformity that bears his name ${ }^{[1]}$. It is an anomaly of the shoulder girdle which is associated with abnormal descent and altered position of scapula. The deformity occurs due to the arrest of caudal migration of the scapula usually during the $9^{\text {th }}$ to $12^{\text {th }}$ weeks of gestation. There is also arrest in the development of bone, muscle and cartilage. Normally, the scapula lies superiorly at the level of the $2^{\text {nd }}$ vertebra and inferiorly at the level of the $7^{\text {th }}$ or $8^{\text {th }}$ vertebra but in patients with Sprengel deformity the scapula is elevated, dysplastic and medially rotated at the inferior pole, with the glenoid directed inferiorly [2]. Many congenital malformations can accompany Sprengel deformity such as Klippel-Feil syndrome, rib anomalies, hemivertebrae and scoliosis ${ }^{[3]}$. In about $50 \%$ of cases with Sprengel deformity, an omovertebral bone or band connecting the cervical vertebral spinous processes to the scapula can be found in up to $50 \%$ of cases ${ }^{[4]}$. The deformity is usually obvious at birth and can progress as the child grows. Cosmetic appearance is the main concern and there is restriction of abduction at the shoulder joint. Due to the result of rotation of the distal angle of the scapula medially, the glenoid faces inferiorly because of which the range of abduction at the shoulder is reduced. Because of binding of the scapula to cervical vertebrae as a result of an omovertebral process there is reduction of the scapulothoracic movement which further impedes the arc of abduction at the shoulder joint.

\section{Materials and Methods}

It is a retrospective study. A total of 5 patients were operated from April 2015 to April 2020. Surgeries were performed by single surgeon who is professionally trained in paediatric orthopaedics. Only unilateral cases were included in our study and cases with bilateral deformity or treated elsewhere were excluded. Advanced imaging like MRI and CT scan were done in selected patients due to socio-economic restraints. Presence of any other congenital anomaly was not an exclusion criteria. Clavicular moresilasation was performed in all the five patients.
Dr. Vishwesh D Chudasam

Resident at Department of Orthopedics, Dr.

Vasantraopawar Medical College

Hospital and Research Center.

Nashik, Maharashtra, India 
Preoperative cosmetic appearance, abduction function of the shoulder, radiographs and associated deformities were noted. Cavendish score was used to analyse cosmetic outcome preoperatively and postoperatively at 2 years after surgery. Range of abduction was assessed clinically with the help of goniometer preoperatively and post operatively at 2 years after surgery.

Cavendish grading system ( $1=$ very mild, $2=$ mild, $3=$ moderate, 4=severe deformity).

Table 1: Cavendish's Classification

\begin{tabular}{|l|l|}
\hline Grade 1 & No visible deformity, patient fully dressed \\
\hline Grade 2 & Bumpy aspect of superomedial angle \\
\hline Grade 3 & Asymmetric shoulder elevation, 2 to $5 \mathrm{~cm}$ \\
\hline Grade 4 & Asymmetric shoulder elevation, $>5 \mathrm{~cm}$ \\
\hline
\end{tabular}

\section{Results}

Three girls and two boys were operated at a mean age of 6.2 years (03-12 years). Out of five patients, four were operated for left shoulder and one for right shoulder. Mean follow up was for 24 months. None of the patients had associated congenital or any other associated anomaly. For cosmetic evaluation mean pre-operative Cavendish score was 2.6 (range 2-4) which reduced to 1.2 (range 1-2) at final review. Mean of shoulder abduction on the involved side was 102.2 degrees (70 - 160 degrees) which increased to 135 degrees at follow up. (120 - 170 degrees). There is an improvement of 32.8 degrees. All the five patients had an omovertebral bar present which was excised. One patient had one complication of opening up of suture and was taken for resuturing at $10^{\text {th }}$ post-operative day. There was no incidence of any other complication in our series and good outcome was achieved.

A good clinical result is demonstrated in below mentioned figure

Table 2: All the five patients had an omovertebral bar present which was excised

\begin{tabular}{|c|c|c|c|c|c|c|c|c|}
\hline Age & Sex & Side & $\begin{array}{c}\text { Pre-operative } \\
\text { Cavendish Score }\end{array}$ & $\begin{array}{c}\text { Post- operative } \\
\text { Cavendish Score }\end{array}$ & $\begin{array}{c}\text { Pre-operative } \\
\text { Abduction Score }\end{array}$ & $\begin{array}{l}\text { Post - operative } \\
\text { Abduction Score }\end{array}$ & $\begin{array}{l}\text { Omovertebral } \\
\text { bone excision }\end{array}$ & MRI \\
\hline $05 y r s$ & Female & Left & 2 & 1 & 100 & 150 & Yes & No \\
\hline $12 \mathrm{yrs}$ & Male & Right & 3 & 1 & 90 & 135 & Yes & Yes \\
\hline 06yrs & Male & Left & 4 & 2 & 100 & 125 & Yes & No \\
\hline 03yrs & Female & Left & 2 & 1 & 110 & 160 & Yes & No \\
\hline $05 y r s$ & Female & Left & 2 & 1 & 110 & 120 & Yes & No \\
\hline
\end{tabular}

\section{Discussion}

Sprengel deformity is a rare disorder of shoulder girdle which leads to limited abduction and shoulder asymmetry. The failure of scapula to descend during the intrauterine period between $9^{\text {th }}$ and $12^{\text {th }}$ weeks has been proposed to induce congenital elevation of scapula ${ }^{[5]}$. Woodward procedure was performed for correction of deformity and improvement of shoulder abduction. Woodward procedure has been performed at different regions of the world by different authors. Since the disorder is very rare, sample size of patients is small universally. The table mentioned below shows the various results published in literature.

We have also been able to reproduce the results as published by other authors. The mean abduction achieved 32.8 degrees is similar to other studies. Improved cavendish score (1.2) is also similar to these studies.

Table 3: Show the Procedure Follow-up period Results and Complications

\begin{tabular}{|c|c|c|c|c|c|c|}
\hline Authors & Procedure & $\begin{array}{c}\text { Follow-up } \\
\text { period }\end{array}$ & $\mathbf{n}$ & Results & Complications & Remarks \\
\hline $\begin{array}{l}\text { Woodward J } \\
\text { W (1961) } \\
{ }^{[6} \text {. }\end{array}$ & $\begin{array}{c}\text { Woodward } \\
\text { scapular } \\
\text { transplantation }\end{array}$ & $\begin{array}{c}2.5 \text { years } \\
\text { (range } 9-60 \\
\text { months) } \\
\end{array}$ & 09 & $\begin{array}{l}\mathrm{H}: \text { mean } 5.2 \mathrm{~cm}(\text { range } 4-8 \mathrm{~cm}) \\
\text { A: mean } 35.5(\text { range } 20-70)\end{array}$ & $\begin{array}{c}\text { Scar and } \\
\text { transient BPP }\end{array}$ & $\begin{array}{l}\text { Scapular to spine judge } \\
\text { correction }\end{array}$ \\
\hline $\begin{array}{r}\text { Carson et al. } \\
(1981)^{[6,8]}\end{array}$ & $\begin{array}{l}\text { Woodward } \\
\text { scapular } \\
\text { transplantation }\end{array}$ & $\begin{array}{c}5.7 \mathrm{y} \\
\text { (range, } 2.5- \\
11 \mathrm{y})\end{array}$ & $\begin{array}{l}11 ; 8 \text { available } \\
\text { for follow up }\end{array}$ & $\begin{array}{l}\mathrm{H} \text { : mean, } 1.6 \mathrm{~cm}(\text { range, } 0.3-4.3 \mathrm{~cm}) \mathrm{A}: \\
\text { mean, } 50^{\circ}\left(\text { range, } 35^{\circ}-60^{\circ}\right) \text {, in patients } \\
\text { with severe preoperative restriction of } \\
\text { abduction }(n=5) \text {; overall mean A: } 29^{\circ} \\
\text { Cavendish gr. } 1 \text { outcome }(6) \text { Cavendish } \\
\text { grade } 2 \text { outcome (2) }\end{array}$ & $\begin{array}{l}\text { Scar, scapular } \\
\text { winging }\end{array}$ & $\begin{array}{l}\text { Subcuticular sutures to } \\
\text { decrease the scar-related } \\
\text { complications; inferior } \\
\text { angle of the scapula to } \\
\text { judge correction }\end{array}$ \\
\hline $\begin{array}{r}\text { Grogan } \text { et al. } \\
(1983)^{[6,9]}\end{array}$ & $\begin{array}{l}\text { Woodward } \\
\text { scapular } \\
\text { transplantation }\end{array}$ & $\begin{array}{l}8 \text { y } 9 \\
\text { months } \\
\text { (range, } 3 \\
\text { months to } \\
17 \text { y) }\end{array}$ & $\begin{array}{c}20 \text { patients, } 21 \\
\text { scapulae; } 13 \\
\text { patients for } \\
\text { follow-up }\end{array}$ & $\begin{array}{l}\mathrm{H}: \text { mean, } 2 \mathrm{~cm}(\text { range }, 0-3.7 \mathrm{~cm}) \\
\quad \text { A: mean, } 37^{\circ}\left(\text { range }, 5^{\circ}-85^{\circ}\right)\end{array}$ & $\begin{array}{c}\text { Transient BPP } \\
(1) ; \text { scar (1); } \\
\text { exostosis } \\
\text { regrowth (1); } \\
\text { exaggeration } \\
\text { of winging of } \\
\text { scapula (1) }\end{array}$ & \begin{tabular}{|} 
Clavicular osteotomy \\
to gain more correction \\
with less risk of \\
neurovascular compression; \\
center of the scapula to \\
judge correction
\end{tabular} \\
\hline \begin{tabular}{|c|} 
Cavendish M \\
E (1972) \\
16, \\
\end{tabular} & $\begin{array}{c}\text { Woodward } \\
\text { scapular } \\
\text { transplantation }\end{array}$ & $\begin{array}{l}\text { Not } \\
\text { reported }\end{array}$ & 5 & $\begin{array}{l}\text { Improved function (4) Cavendish grade } \\
1 \text { outcome (1); grade } 3 \text { outcome (3) }\end{array}$ & Scar(1) & - \\
\hline
\end{tabular}




\begin{tabular}{|c|c|c|c|c|c|c|}
\hline $\begin{array}{c}\text { A A Ahmad } \\
(2010)^{[6,11]} .\end{array}$ & $\begin{array}{c}\text { Modified } \\
\text { Woodward's } \\
\text { procedure }\end{array}$ & $\begin{array}{c}36.2 \text { mo } \\
\text { (range, 24- } \\
51 \mathrm{mo})\end{array}$ & $\begin{array}{c}15 \text { shoulders, } \\
11 \text { patients }\end{array}$ & $\begin{array}{c}\text { A: } 49^{\circ} \text { Cavendish grade } 1 \text { outcome (7); } \\
\text { Cavendish grade } 2 \text { outcome (8) }\end{array}$ & $\begin{array}{c}\text { Winging of the } \\
\text { scapula (4); } \\
\text { keloid (4) }\end{array}$ & $\begin{array}{c}\text { Increased postoperative } \\
\text { range of abduction } \\
\text { compared to Woodward's } \\
\text { procedure }\end{array}$ \\
\hline
\end{tabular}

BPP - Brachial plexus palsy; H - Scapular lowering obtained; A - Improvement in abduction; $\mathrm{y}$ - Years; $n$ - The number of patients included in the study;

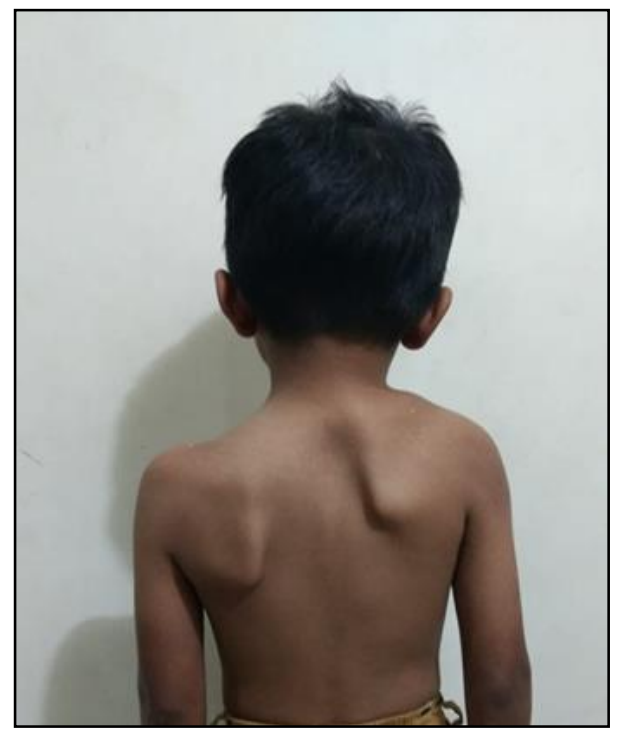

Fig 1: Clinical image showing pre-operative Cavendish score 3

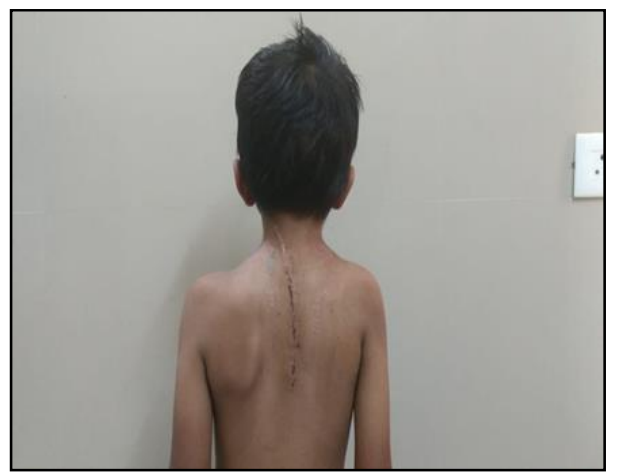

Fig 2: Post-operative image showing Cavendish score reduced to 1.

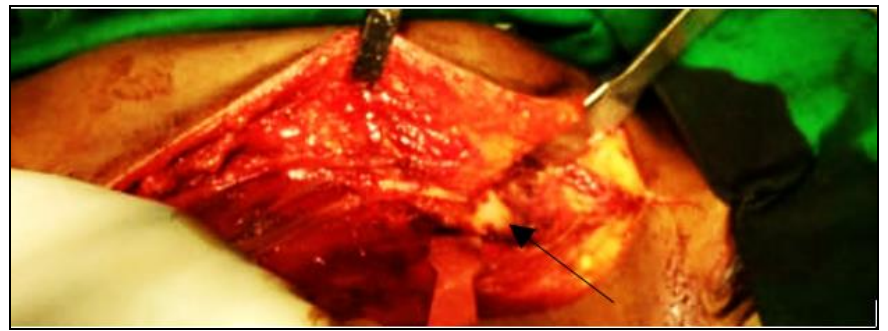

Fig 3: Intraoperative image showing omovertebral bone bar being excised.

\section{Conclusion}

Woodward procedure is an effective surgical method to correct Sprengel's deformity and can be easily reproduced in spite of socio-economic constraints.

\section{References}

1. Sprengel O. Die angeborene vershiebung der schulterblattes nach oben. 1891; 42:545.

2. Kamal YA. Sprengel deformity: An update on the surgical management. Pulsus J. Surg. Res. 2018; 2(2).

3. Ross DM, Cruess RL. The surgical correction of congenital elevation of the scapula:A review of seventyseven cases. Clin Orthop Relat Res. 1977; 125:17-23.
4. Hamner DL, Hall JE. Sprengel deformity associated with multidirectional shoulder instability. J Pediatr Orthop. 1995; 15:641-3.

5. Siu KK, Ko JY, Huang CC, Wang FS, Chen JM, Wong T et al. Woodward procedure improves shoulder function in Sprengel deformity. Chang Gung Med J. 2011; 34(4):403-9.

6. Kadavkolan AS, Bhatia DN, DasGupta B, Bhosale PB. Sprengel's deformity of the shoulder: Current perspectives in management. International journal of shoulder surgery. 2011; 5(1):1.

7. Joe W. Woodward. Congenital elevation of the scapula: Correction by release and transplantation of muscle origins. J Bone Joint Surg Am. 1961; 43:219-28.

8. Carson WG, Lovell WW, Whitesides TE Jr. Congenital elevation of the scapula. Surgical correction by the Woodward procedure. J Bone Joint Surg Am. 1981; 63:1199-207.

9. Grogan DP, Stanley EA, Bobechko WP. The Congenital undescended scapula surgical correction by the Woodward procedure. J Bone Joint Surg Br. 1983; 65:598-605.

10. Cavendish ME. Congenital elevation of the scapula. J Bone Joint Surg Br. 1972; 54:395-408.

11. Ahmad AA. Surgical correction of severe Sprengel deformity to allow greater postoperative range of shoulder abduction. J Pediatr Orthop. 2010; 30:575-81. 